Thematic article

\title{
"From the Initial Steps to the Concept of Online Education" - Teacher Experiences and Development Directions Based on Feedback from Online Education Introduced During the Pandemic
}

\author{
Mónika Rajcsányi-Molnár', Anetta Bacsa-Bán² \\ Recommended citation:
}

Rajcsányi-Molnár, M., \& Bacsa-Bán, A. (2021). "From the initial steps to the concept of online education" - Teacher experiences and development directions based on feedback from online education introduced during the pandemic. Central European Journal of Educational Research, 3(3), 33-48. https://doi.org/10.37441/cejer/2021/3/3/9612

\begin{abstract}
The pandemic situation caused by COVID-19 has challenged the education system, not only in Hungary, but everywhere in the world. The use of information and communication technology in education, including higher education, has transformed students' expectations and at the same time, redefined the role of the online educator. This is because online teaching and learning is significantly different from teaching-learning in a traditional environment, and educators need to rethink their role in the learning and teaching paradigm. Our higher education institution has developed a new learning-teaching concept based on the experience of distance education introduced as a result of the pandemic situation. The research described in the study and the corresponding developments are shared as good practice for other higher education institutions.
\end{abstract}

Keywords: online education; pandemic; higher education

\section{Introduction}

Here, the pandemic situation caused by COVID-19 has challenged the education system not only in Hungary, but everywhere in the world. Public education institutions were strongly affected by the transition to online education. In higher education, almost all domestic institutions had foundations, which served as a good basis for quick reaction, and which could serve as a good starting point for future developments and systems by taking advantage of digital education (Demeter et al, 2020). However, the goal was the same at all levels of education. The immediate continuation of education had to be ensured so that the level of readiness of the students had to be kept in mind. In addition, we had to take on a strong role in supporting learning. In the case of higher education, we primarily had to answer how students and teachers are prepared for the transition, and we also had to examine whether the teaching method is effective beyond the lecture hall / laboratory framework, when transferred to technological tools.

\section{Background, theoretical framework}

Even though Hungarian professionals are familiar with the new developments and learning technologies related to mass distance learning courses, mass online education, or so-called full-time distance education, did not have well-founded references in Hungary (Deés, 2020; Hargitai et al., 2020). Worldwide, in the last decade, these radical organizational and methodological solutions have been accompanied by remarkable professional debates, and perhaps this also played a role in the fact that Hungarian higher education was not really affected by significant international experiments in online education. In many cases, in Hungarian higher education, online solutions, full content management services and educational administration were integrated only in the

\footnotetext{
${ }^{1}$ University of Dunaújváros, Dunaújváros, Hungary; molnarmo@ uniduna.hu

${ }^{2}$ University of Dunaújváros, Dunaújváros, Hungary; bana@uniduna.hu
} 
teaching of single subjects or modules (Molnár et al., 2020). This particular situation has been significantly transformed by the crisis management of education over the past year or so in Hungary, as well as in many countries around the world. Overnight, almost without precedent, the total transition to remote, online education and learning became a compulsive solution (Benedek, 2020).

In order to talk about online higher education at all, not only the techniques, teachers and methods, but also the recipients and students must be ready for development (Deés, 2020; Rajcsányi-Molnár et al., 2021).

The pandemic period also created or highlighted new concepts (Molnár et al., 2020; Sipos et al., 2020). Distance education, or online education, was introduced in education; however, these two concepts differ somewhat, and if we focus on the roles of educator, it is worth separating their basics too.

Distance learning is a form of education where the teacher and the student are not in the same place. The student studies alone, independently for most of the training time and participates in consultations for a smaller period. The curriculum is made available to the student by the educational institution for purposes of home learning, while during the consultations for which any form of contact can be used from a face-to-face meeting to the Internet to telephone etc. the student deepens his / her self-acquired knowledge. Education in this case, therefore, takes place by bridging some distance, so students must learn to study independently. Only those students who are able to meet this new role, who are properly motivated, ready for continuous learning and capable of taking full advantage of two-way communication can be successful in distance learning. The educator's role must also be reconsidered, for now it is the student in the center of the learning process and the teacher becomes a guide and helper (Gonda, 2020).

Online education is actually also distance learning, but in this case simultaneity and synchronicity are in focus. Teacher and students are together in real time by using software and IT devices (laptop, tablet, mobile phone etc.). In addition to giving presentations, there are opportunities for comments, questions, project assignments, discussions, attaching movies and videos, solving tasks, group work etc. (Gonda, 2020).

Distance education, which was introduced in higher education, is between the two; it is in fact a mixed form of education. As a matter of fact, it tries to implement distance learning based on online learning without a physical presence, which offers many opportunities but, of course, it also has its limitations.

As opportunities, we can enumerate the followings:

- flexibility in time;

- lack of localization;

- allows the development of individual learning pathways;

- cost-efficiency;

- due to microcontents, it supports the filling in of idle times and it allows study to be done in smaller units;

- supports the creation of recorded curricula that can be retrieved later;

- supports the planning of transparent and documented learning processes;

- supports the breaking of geographical constraints and the creation of virtual learning communities;

- once the emergency has been lifted, education can proceed at higher quality level.

The followings can be considered as limitations:

- low level of digital proficiency of the instructor and / or student;

- lack of equipment;

- lack of personal, direct contact;

- skill development and practical training involves more investment of time by the instructor (Bereczki et al., 2020).

Based on the research in the topic, the development of online education can be summarized as follows (Dabbagh et al., 2005). 
Table 1. Historical background to the development of online distance learning

\begin{tabular}{|c|c|c|}
\hline Period & Focus point & Educational characteristics \\
\hline 1975-1985 & $\begin{array}{c}\text { Programming; } \\
\text { Computer } \\
\text { assisted learning }\end{array}$ & $\begin{array}{l}\text { Behaviorist approaches to learning } \\
\text { and instruction; } \\
\text { Programming to build tools and } \\
\text { solve problems; } \\
\text { Local user-computer interaction. }\end{array}$ \\
\hline 1983-1990 & $\begin{array}{c}\text { Computer-Based } \\
\text { training; } \\
\text { Multimedia }\end{array}$ & $\begin{array}{l}\text { Use of older CAL models with } \\
\text { interactive multimedia; } \\
\text { Dominancy of passive learner } \\
\text { models; } \\
\text { Constructivist perspectives begin to } \\
\text { appear in educational software } \\
\text { design and use. }\end{array}$ \\
\hline 1990-1995 & $\begin{array}{l}\text { Web-based } \\
\text { education and } \\
\text { training }\end{array}$ & $\begin{array}{l}\text { Internet based content delivery; } \\
\text { Active learner models; } \\
\text { Constructivist perspectives; } \\
\text { Limited end-user interactions. }\end{array}$ \\
\hline 1995-2005 & eLearning & $\begin{array}{l}\text { Internet-based flexible courses; } \\
\text { increased interactivity; } \\
\text { online multimedia courses; } \\
\text { constructivist and cognitive models; } \\
\text { Remote user-user interactions. }\end{array}$ \\
\hline 2005 - now & $\begin{array}{l}\text { Mobile learning } \\
\text { and social } \\
\text { networking }\end{array}$ & $\begin{array}{c}\text { Interactive distance learning } \\
\text { programs via online systems on } \\
\text { social network; } \\
\text { learning is facilitated by wireless } \\
\text { devices such as PDAs, smart phones } \\
\text { or laptops; } \\
\text { learning with portable technologies } \\
\text { where the focus is on the mobility of } \\
\text { the learner. }\end{array}$ \\
\hline
\end{tabular}

Source: Keengwe \& Kidd 2010: 534

\section{Research design and Methods}

The authors state that traditional education 1. is tied to the place and the presence of teachers and students, 2. it takes place in real time 3. it works under the control of the teacher, 4. it uses linear educational solutions. By taking advantage of the new technological opportunities in online teaching and learning environment, asynchronous and real-time communication will become informal and dynamic, a wide range of pedagogical practices, active learning and student-centered pedagogical attitudes may become a typical feature (Keengwe et al., 2010; Deés, 2020).

The use of information and communication technology has transformed students' expectations. At the same time, the role of the online educator is seen as new and more complex. Online teaching and learning are different from teaching-learning in a traditional environment and educators need to rethink their role in the learning and teaching paradigm (András et al., 2016a., Keengwe et al., 2010).

The role of the online educator can be defined in four categories: pedagogical, social, managerial, and technical-technological role. The pedagogical role means the teaching methods, while the social role serves to create the environment necessary for online learning. The leadership role includes the organization and scheduling of education, the setting of objective goals, rule-setting and decision-making, and the technical role means the technological knowledge and knowledge transfer of educators.

Online curriculum development and teaching requires special skills that educators must acquire in order to be successful in learning and teaching (Howell et al., 2004). In this process, it is also a challenge that 
educators need to change their pedagogical practices (Demeter et al., 2019) and acquire the right skills to become effective online educators. (Smith, 2005).

There is evidence that traditional teaching roles are changing in an online environment (Keengwe et al., 2010). After all, educators share their role with all education organizers and technical assistants who have not been directly involved in the educational process so far.

But the educator sometimes takes on the role of technologist as the planner of education even without the help of institutional administration (Keengwe et al., 2010). In addition, the educator appears as a facilitator, teacher, organizer, evaluator, mentor, role model, counselor, coach, supervisor, problem solver and liaison officer. (Liu et al., 2005; Riffee, 2003).

Higher education should prepare students to reinterpret rites that were previously associated with education, in the context of digital education (Szüts, 2020). Class attendance (tied to space and time), the temporal organization of classes; availability (presence) of trainers, personal consultation (communication); the ritual relationship of participants, the master-student relationship (the importance of the teacher's personality) and the student-student relations (class or groupmates); access to knowledge (availability of curriculum); or just taking notes (recording knowledge) is placed on new foundations. "Within the framework of written communication various everyday activities related to the sharing of teaching aids and the organization of class visits were included; intensifying the possibility of student-teacher communication by providing the possibility of frequent message exchange" (Szüts, 2020).

Numerous studies have already shown that teachers themselves are key players in the quality of education, as the 2007 McKinsey report puts it, the teacher is at the heart of successful education systems, meaning the quality of the school system depends on teacher performance (McKinsey, 2007). Although many other factors are decisive (Molnár, 2021), we cannot ignore the role of teachers in higher education.

These role changes / transformations apply to the educators of the education system as a whole, regardless of the level we are talking about, and whether the particular educator has a pedagogical qualification or not. Therefore, it is important to know how our educators perform in this role, how they manage to hold on in the field of online education, what problems, issues, and opportunities the digital semesters of the pandemic brought to them.

UNESCO also asks institutions of the countries of the world to document and preserve data and documents related to the COVID-19 pandemic within the framework of the Memory of the World (MoW) program. (UNESCO, 2020)

By researching, analyzing, and sharing our research results, we also are aiming to contribute to the realization of this goal.

\section{Research design and Methods}

In this short section please explain as clear as possible, what kind of methods you used, why you chose these methods, and what the relevant circumstances of the data collection and the analyzing process were. The more reliable this description is, the more impact you can make.

The University of Dunaújváros has been developing the conditions for online and digital education for years to increase the number of correspondence students and to support student success (Szabó et al., 2017). Due to this, a significant number of online courses are available (77 Hungarian and 28 English language disciplines) and we were among the first institutions that introduced video-supported online education.

We have taken special care in finding a balance between online and traditional education, either within a training course or in the subject matter of a discipline. Our research, which reached 1134 active Hungarian and 167 active foreign students of our higher education institution, was extended to all of our (125 person) teaching staff with the help of a mirror questionnaire.

Our study was an exploratory one. By not having particular prior knowledge, we did not form hypotheses, but rather set research questions. 
We designed our study on the basis of the following questions:

- How did our teachers experience digital education?

- What difficulties and problems did they face?

- What opportunities did education provide them?

- In which area(s) can our institution help and support them?

- And finally: How do they see the future of online education?

Our results suggest that higher education continues to have a role to play in exploring the experiences of online education by solving its problems, and our results identify further actions to be performed.

The sample

We opted for interviewing the full staff. At the University of Dunaújváros, we involved 125 active lecturers in our courses in the second semester of the 2019/2020 academic year.

The instructors were contacted via e-mail using the data register of the Neptun system, where they received a link to our online questionnaire, backed by our personal e-mail.

The survey was successful. In the case of our instructors, 43 people answered the questionnaire, which resulted in a $34 \%$ response rate. In this paper, we present the results of the research conducted among our instructors.

\section{Results}

\section{Background variables}

In terms of gender distribution, $45 \%$ of the interviewed teachers are women and $55 \%$ are men.

In terms of their age distribution, our responding instructors follow the curve of normal distribution, shifting toward higher age groups. Most of them are in the 36-45 and 46-55 age groups. In terms of their position, the same number $(29-30 \%)$ was answered by teaching assistants and associate professors, while a smaller number (14-15\%) were represented by assistant professors and college / university professors.

In terms of their fields of study, the interviewed colleagues represent primarily the fields of social sciences, engineering, and economics in accordance with our courses / specializations.

Figure 1. Distribution of the instructors in the sample by discipline

\section{Instructors and their taught field of science}

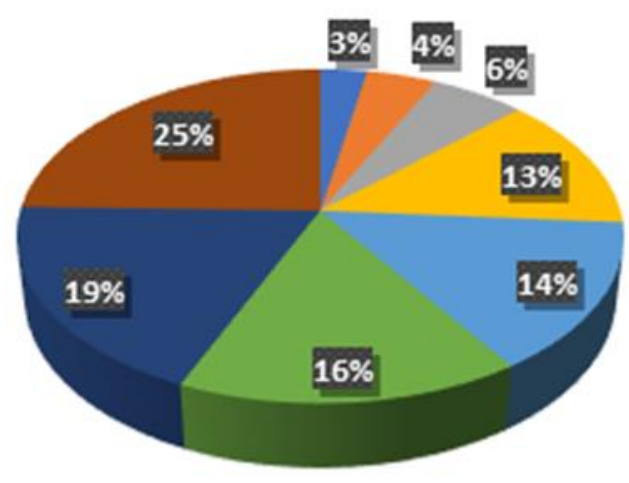

- Law

= Nature Sciences

nedagogy

= Humanities

Informatics

Economics

Technical Sciences

Social Sciences 
The interviewed lecturers have been working in higher education for an average of 14.24 years. The number of their years spent in higher education follows normal distribution, peaking around the average and shifting towards higher years.

Figure 2. Number of years spent in higher education in the sample of teachers

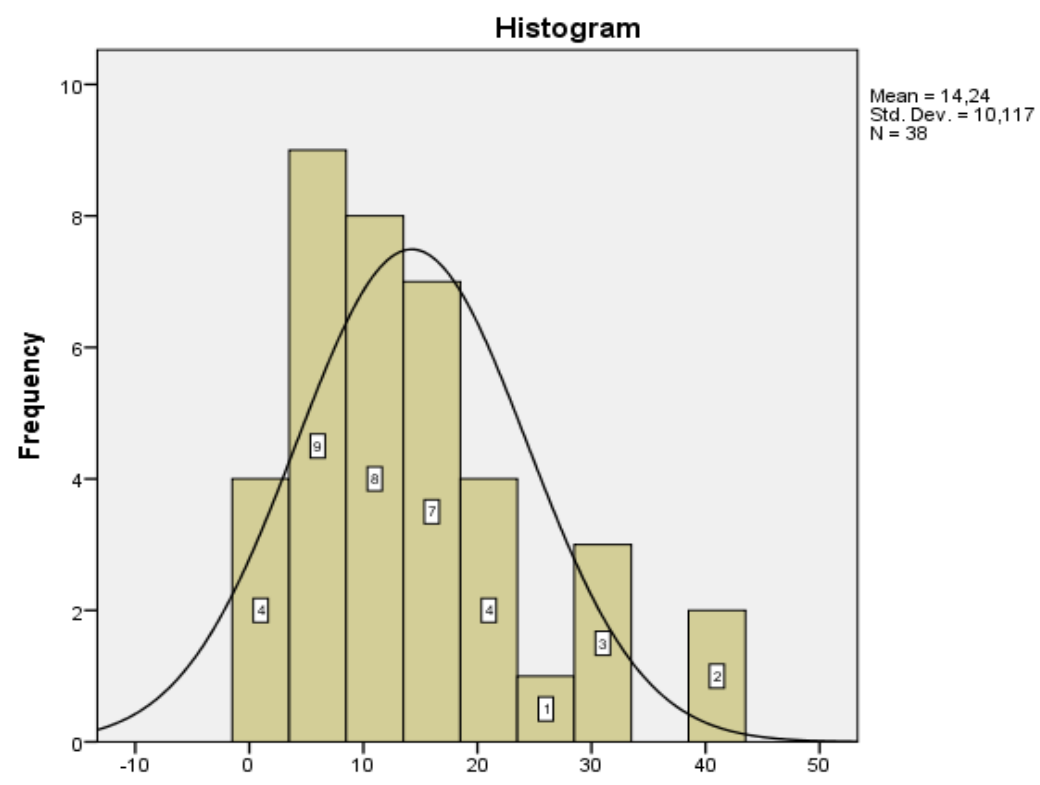

Digital competencies and online activities

Our interviewed instructors value the level of their own digital competencies as follows. In terms of information retrieval, the majority consider themselves a master-level user, while in other areas, they consider themselves a stand-alone user. Instructors are the most uncertain about online problem solving. For some, this is not a problem, while about the same proportion were those who had only basic knowledge here. This field showed a correlation with their areas of teaching. The lecturers in the field of informatics proved to be at masterlevel, while the lecturers in the field of teacher training were at the most basic level.

Table 2. Level of digital competencies of the instructors interviewed

\begin{tabular}{lccc}
\hline & basic user & standalone user & $\begin{array}{c}\text { master level } \\
\text { user }\end{array}$ \\
\hline $\begin{array}{l}\text { Online information } \\
\text { search/processing }\end{array}$ & 2 & 18 & 23 \\
$\begin{array}{l}\text { Online content creation } \\
\text { Online communication and } \\
\text { collaboration }\end{array}$ & 5 & 23 & 14 \\
$\begin{array}{l}\text { Online problem solving (in } \\
\text { case of a technical } \\
\text { problem) }\end{array}$ & 2 & 23 & 18 \\
$\begin{array}{l}\text { Online security (e.g. data } \\
\text { management, etc.) }\end{array}$ & 14 & 15 & 14 \\
\hline
\end{tabular}

Many of the forms of online education in our institution already have a long tradition, so when asked what kind of online education activities they have done on a regular basis, our colleagues listed their previous online education activities in the forms of online contact hours, exams, or consultations. 
Figure 3. Online activities performed regularly by the instructors in the sample

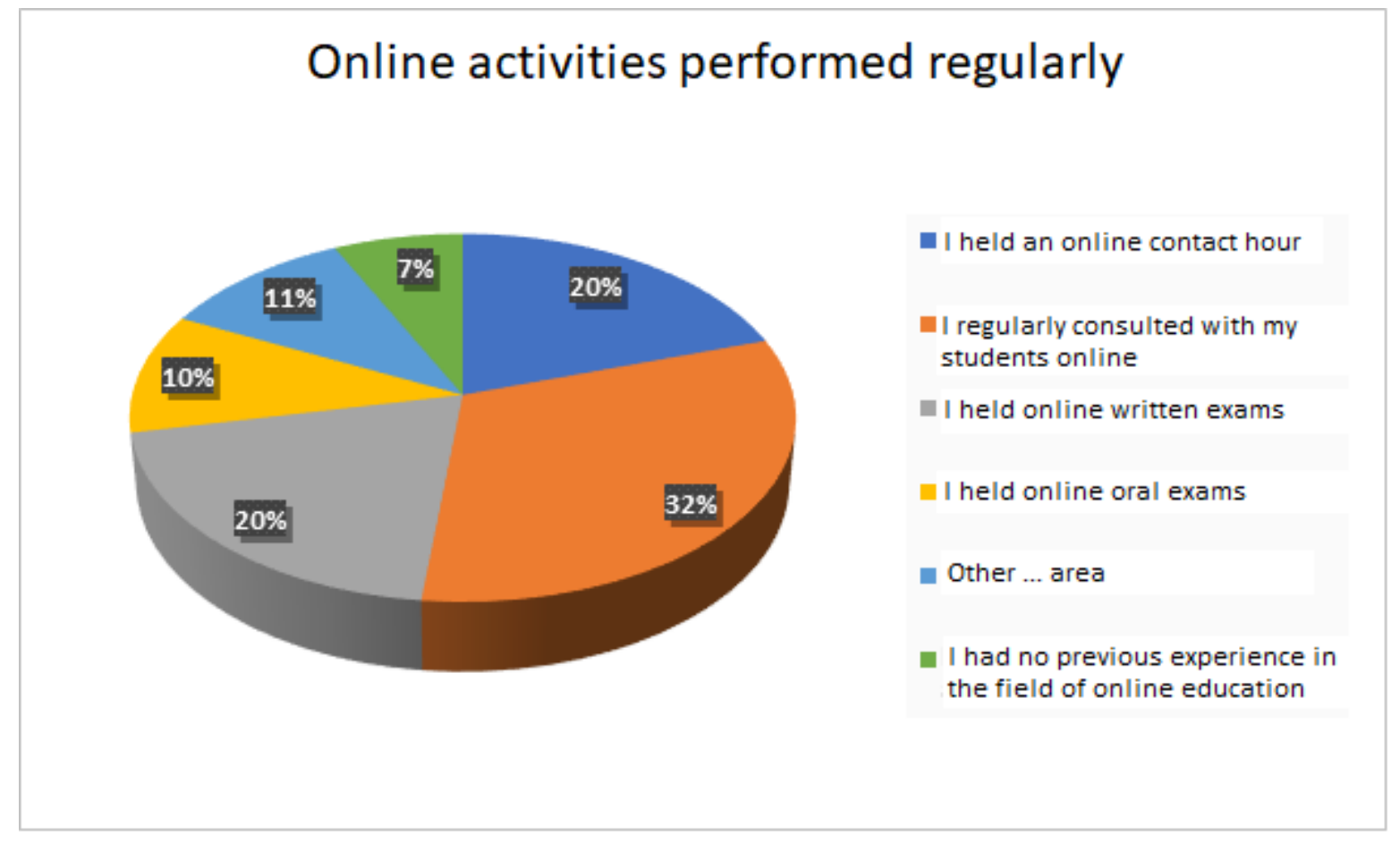

The main platform for these online activities was e-learning - mostly in the university's Moodle system, or our Neptun system, which was, of course, associated with tasks shared by email.

Online education during the emergency caused by the pandemic

One of the distinguished aims of our study was to examine the effects of the state of emergency on our online education and digitization at our university.

Therefore, it was important for us to see how much strain this activity puts daily on our colleagues. We found that most of them spent more than 8 hours a day working in the digital space, and there was a very small number of colleagues for whom online activity fell below 5 hours.

Our institution has developed a set of procedures for digital education for both our teachers and students, but we were curious about how our colleagues conducted their educational activities according to or despite these.

As one can see it in the diagram, mainly live video lectures and exercises were held, followed by video or PowerPoint lectures and teaching materials uploaded to modular distance learning interfaces. A smaller number of email curricula was sent, and the number of presentations or other educational activities was almost insignificant. 
Figure 4. The main forms of online educational activities of teachers

\section{Main form of educational activity}
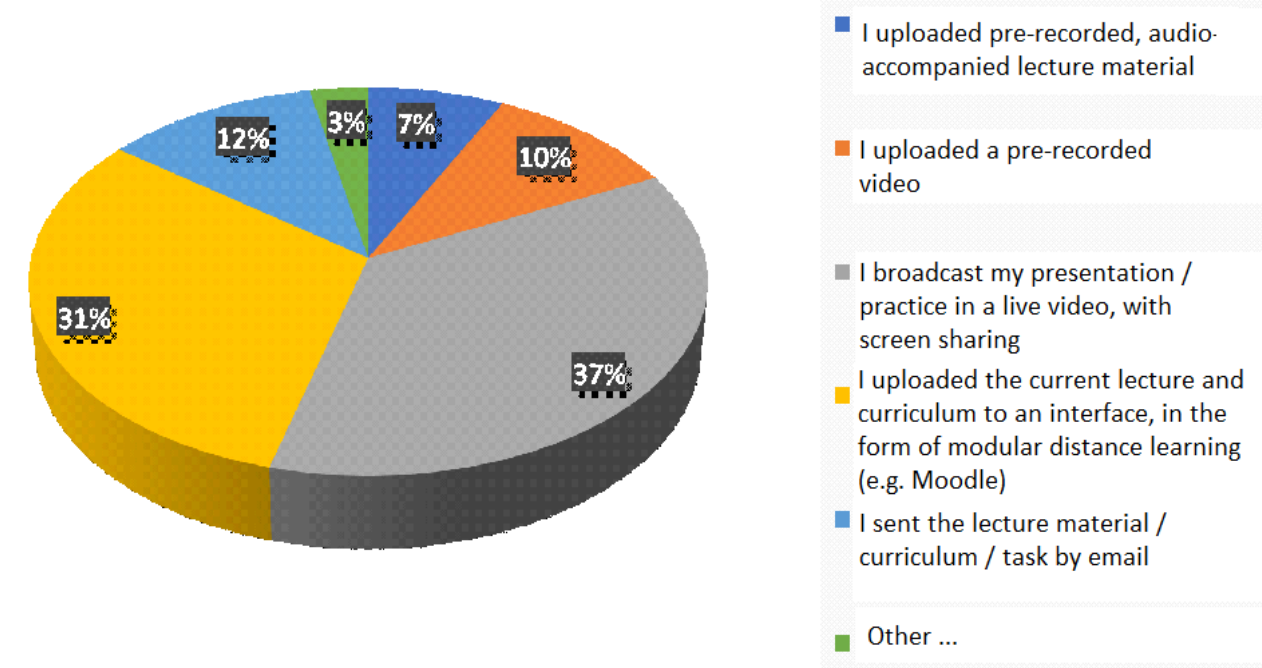

In the live lessons, the instructors strained to involve the students in several ways: primarily by giving them an independent assignment; asking questions, discussing a topic, or trying to work on a topic using cooperative learning techniques.

During online education, in addition to the processing of the topics and the acquisition of the curriculum, another crucial issue is the examination, the use of various examination methods. Our instructors mostly opted for submitting the tasks, but in an almost equal proportion they also checked the acquisition of knowledge through online written and / or oral exams.

Figure 5. Examination methods used by the instructors in the sample

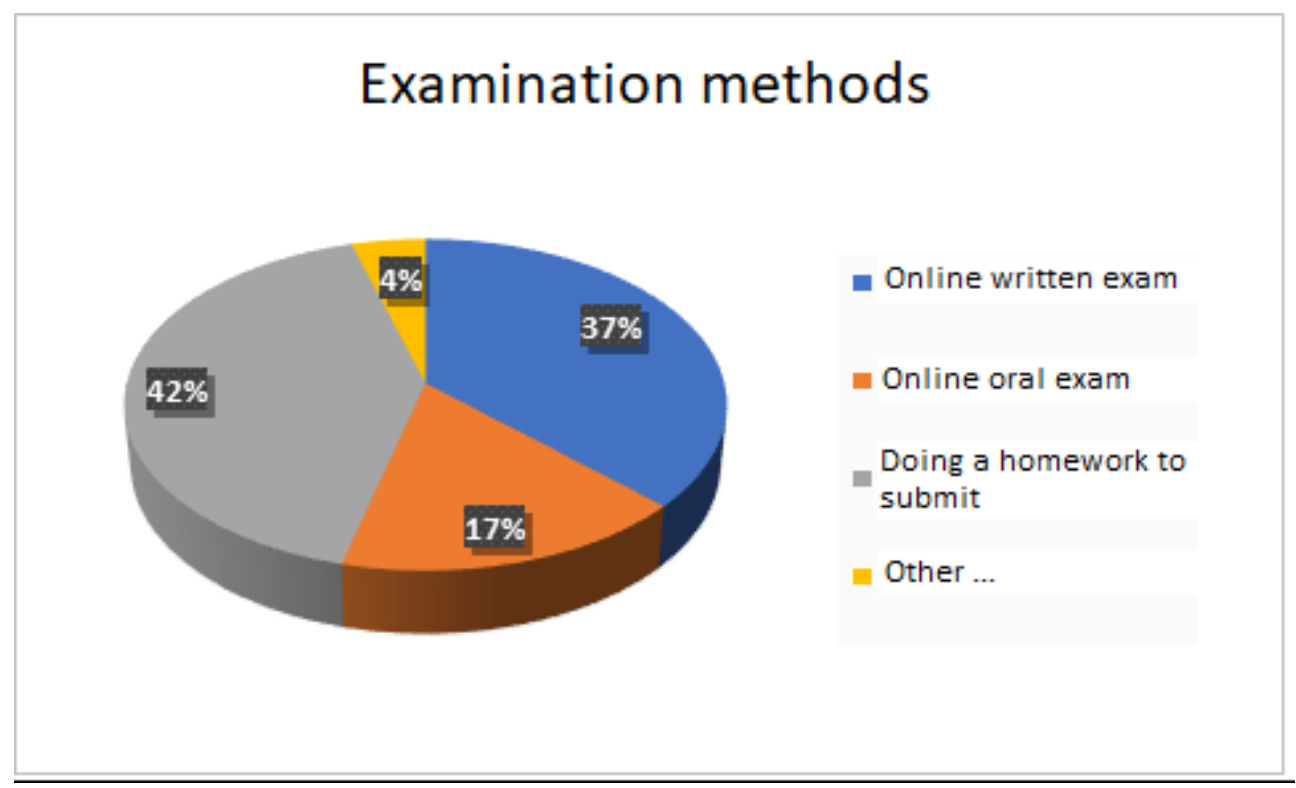

In the live lessons, the instructors strained to involve the students in several ways: primarily by giving them an independent assignment; asking questions, discussing a topic, or trying to work on a topic using cooperative learning techniques.

During online education, in addition to the processing of the topics and the acquisition of the curriculum, another crucial issue is the examination, the use of various examination methods. Our instructors mostly opted 
for submitting the tasks, but in an almost equal proportion they also checked the acquisition of knowledge through online written and / or oral exams.

Experiences, difficulties, opportunities in connection with online education

In the following, we asked our respondents to evaluate their experiences and impressions about online education along particular aspects. The availability of their own curricula, the quality and efficiency of their online education came first. Unfortunately, the institutional equipment supply and the digital preparedness of the staff and students were rated poorly. Based on this experience, we took more action even during the semester by organizing courses and digital competence development trainings at the university.

Please rate your impressions and experiences on online education during the semester on a scale of 1 to 5 in the following areas! $(1=$ insufficient; $5=$ excellent $)$.

Figure 6. Teachers' impressions regarding online education

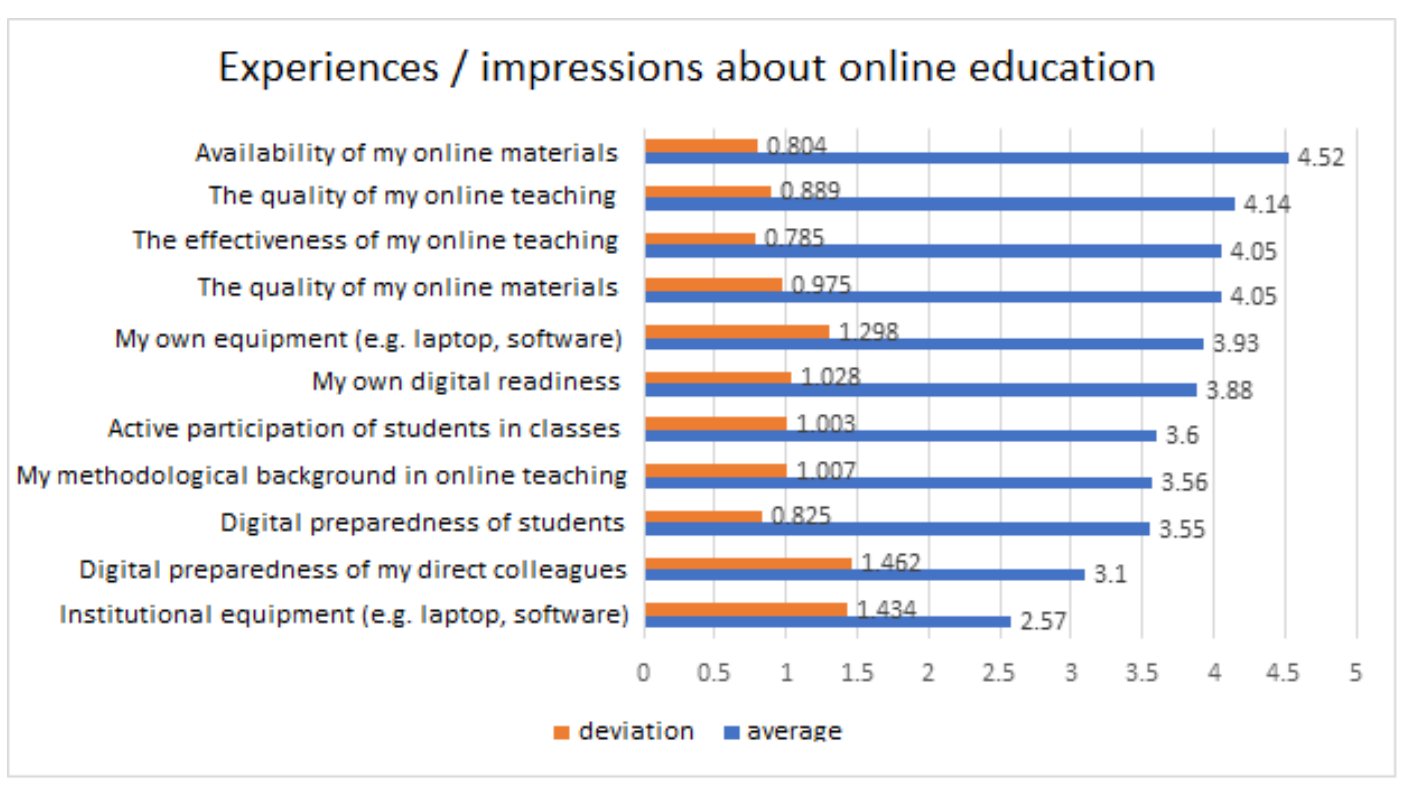

We then asked them to rate the listed aspects as factors of difficulty that posed a major challenge for them during the online semester. Clearly, the new administrative burdens posed the greatest challenge and problem for all of our teachers, in addition to the lack of opportunities for direct, personal contact, and the impossibility of separating work and family life as a result of working from home. Least of all problems were contacting the study office or ensuring information security. 
Please rate the extent to which the following issues have caused you difficulty in online education $(1=$ no difficulty at all; 5 = great difficulty).

Figure 7. Difficulties experienced by teachers in online education

\section{Difficulties encountered during online education}

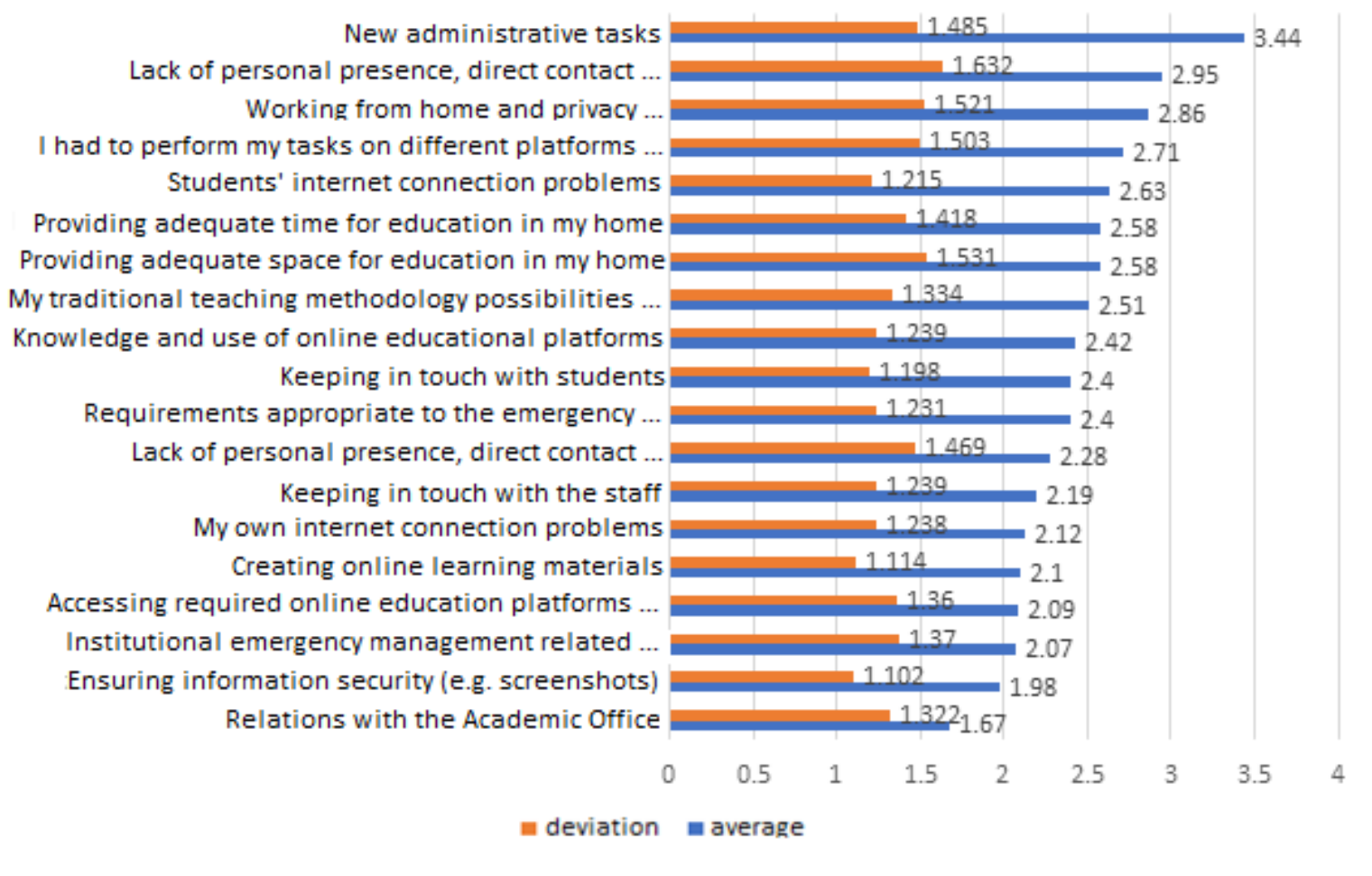

In the following, we asked them for their opinion on the statements related to online education, proving what the main benefits and experiences of online education were for them.

We can highlight from these that our lecturers are expecting to see more frequent use of online education in the future, just as they agreed that online education was more burdensome and involved more administration. Similarly, there was a consensus that online education has made them more proficient in online communication.

Please rate how much you agree with the following statements! $(1=$ strongly disagree; $5=$ strongly agree $)$

Figure 8. Agreeing with statements about online education

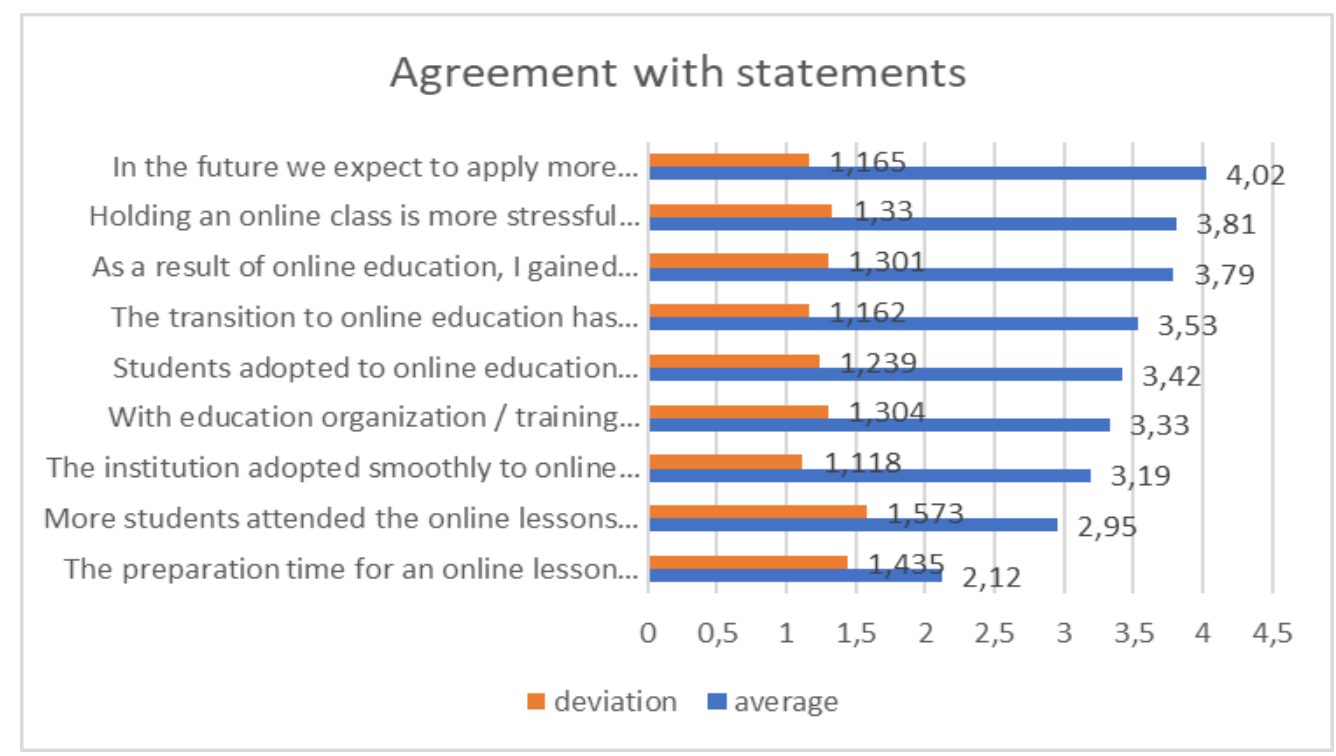


The lecturers at our university, although with a large standard deviation value $(2,474)$, rated the educational activity of the institution on a scale from 1 to 10 , as 6,86 , so above the mean.

It was important for us to summarize the difficulties and benefits of online education in the form of an open-ended question. Our teachers' answers are listed below.

What has been the biggest benefit of online education for you?

Benefits:

- $\quad$ more organized, better structured curriculum

- $\quad$ more, better quality teaching material

- development of digital competencies, new tools, new platforms

- professional development

- $\quad$ saving time and money (flexibility, travel), increased work efficiency

- $\quad$ students' ability to collaborate, more effective learning, activity and activating

- the university responded very quickly to the Coronavirus pandemic in its communication

- "It has shown us that the internet is completely breaking down boundaries. The desire for knowledge and the achievement of competencies are individual and can only be limited by internal motivation."

What caused you the greatest difficulty during online education?

Difficulties:

- lack of adequate digital competencies

- $\quad$ an unprepared, and in many cases unsuitable, work environment and IT equipment at home for working online

- $\quad$ limited number of forms of work, uncontrollability of some work processes, difficult / unsolvable monitoring, lack of motivation because of no presence of instructors

- $\quad$ work-private life balance, complete disappearance of private time, increased responsibilities on the part of all organizational units

- $\quad$ increased administrative burdens

- $\quad$ impersonality, difficult relationship with students

- Internet and Moodle system related problems

- $\quad$ lack and inadequate ICT tools

- $\quad$ preparation of online education materials

- $\quad$ suggestion: creating an online educational etiquette

Finally, we asked the lecturers how they expect the pandemic will affect the Hungarian higher education in the future. The spread of online education is clearly inferring from their responses. However, it can be also perceived that they still expect the prevalence of traditional education. 
Figure 9. Future impact of the pandemic on education

\section{In your opinion, to what extent will the pandemic reshape domestic higher education in the future?}
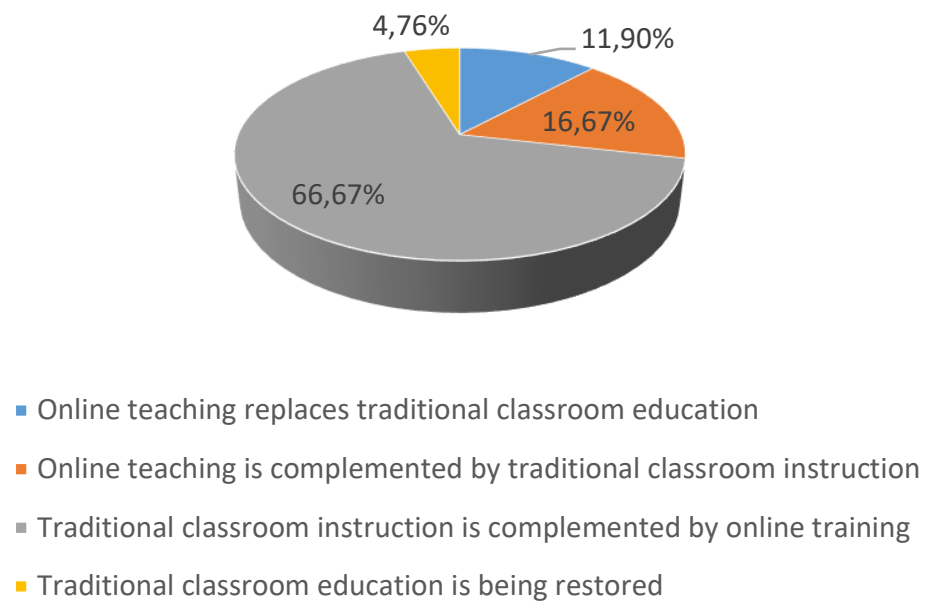

While students thought that we tend to replace traditional (classroom) education, lecturers think that the role of traditional education is much stronger.

Table 2. Opinions of the lecturers and students in the sample on the future role of online and traditional education

\begin{tabular}{lcc}
\hline & Lecturer & Student \\
\hline Online replaces traditional & 11,9 & 29,37 \\
Online complemented by traditional & 16,7 & 25 \\
Traditional complemented by online & 66,7 & 40,48 \\
Traditional restored & 4,8 & 5,16 \\
\hline
\end{tabular}

Our present study confirmed our assumption that higher education still has a role to play in exploring the experience of online education, solving its problems and our results involves further actions.

As a result, our institution identified new areas for development, which are described in the following section under the e-DUE concept. The main elements of the initiated concept, include e-learning framework and curriculum development, trainings, coaching and support to the instructors, and extended helpdesk operations. With the brief introduction of the e-DUE concept, we aim to highlight the importance of such initiatives and provide a good basis for exchanging experiences with other higher education institutions.

\section{The e-DUE concept}

Distance education, which triggers personal presence and traditional classroom training, has posed challenges to both students and faculty due to the altered teaching methods and opportunities. Based on the experience so far, and in response to the feedback received, a number of changes and development plans have been formulated for the future, which are intended to support quality online education with modern digital content, tools and methods to support student success. In order to be able to perform the increasingly important online and digital educational tasks with the highest possible quality and efficiency, the e-DUE concept has been developed, which will enable learning and teacher-student interaction with unified solutions. 
The objectives of the e-DUE project are as follows:

- Professional service for domestic and foreign students in accordance with the needs of online education and content services.

- $\quad$ Strengthening and further developing traditional education (based on the experience gained in previous years), incorporating online communication spaces into education.

- Development of a unified, easy-to-follow and easy-to-use user interface (LMS, Webinar), both in terms of security and function.

- $\quad$ Providing a helpdesk for both students and faculty that includes all support for online education.

- Renewal of the Online Studium organizational unit dealing with digital content development, extension of the online services at the University of Dunaújváros.

The main content elements and areas for development defined by the e-DUE concept are the following:

- A complete overhaul of the Moodle framework for online education, unification of currently isolated online platforms with more modern functionality.

- Defining the design of a new DUE standard online course.

- Online implementation of classroom education (possible replacement where appropriate). Design of a webinar lab.

- HELPDESK support and services development, provision of instructional videos.

- Providing digital and collaborative educational support and methodological training.

- Development of fully online degree courses for foreign students (in English).

- Development of the Online Studium organizational unit: purchase of equipment necessary for the effectuation of the e-DUE project, provision of personal and other conditions.

By developing an integrated online education system, the long-term goal of the e-DUE project is to modernize the framework and tools to support online education, expand online educational content, develop the competencies needed for education in digital form, and thanks to all this increase, the satisfaction and success of the participants in the educational process.

\section{Summary}

We can say that no matter what the antecedents of digitization were in higher education, institutions were clearly not prepared to move to full online education.

Even the precise definition of the interpretive framework and the concepts caused confusion as well as what we consider to be digital education, online implemented traditional education, distance education, or distance learning.

Higher education institutions encountered three relevant problems during the shift to online education:

- lack of sufficient digital educational content,

- lack of tools for digital education, and

- methodological shortcomings for digital content delivery, for evaluations and for the education process.

It should be noted that online teaching requires doing a step forward in traditional pedagogy in order to acquire new knowledge and pedagogical practices. We also need to see that "not all educators are capable for teaching in an online environment" (Keengwe et al., 2010). Furthermore, it has also become clear that instructors cannot be expected to know intuitively how to teach effectively online.

We must therefore break up with the view that the teacher is the sole beholder of knowledge, while still remaining central to education in his / her new roles, also alongside the student. (Szüts, 2020.) Based on the experience gained in online education during the pandemic, we may presume that educator roles are significantly transformed, filled with new content, while some tasks are pushed into the background. 
The reinterpreted role of teacher / educator can be grasped in the following:

1. Tutor: In the digital transformation, the learner's independent learning plays an important role, and the emphasis shifts from teaching to learning. In this process, the teacher moves away from the learner in space and assists his or her work as a tutor. "Tasks are problem-solving in nature, facilitating the use of knowledge within a given situation. In this process, the tutor... has a central, leading role." (Imets, 2007)

2. Facilitator: The role of facilitator has been appreciated in the context of digital technology, as the teacher needs to facilitate change by supporting creative processes and collaboration between group members. He / She does not intervene in content issues in such a role but supports the fulfillment of individual interest. In facilitating digital transformation, the emphasis is on technology adaptation.

3. Moderator: As digital pedagogy relies on the phenomena of internet communication and media, there is a need for a moderator to keep the discussions on collaboration and communication in mind, especially when expanding the classroom. Learning already takes place among equal participants, so the lack of hierarchy is replaced by the role of moderator.

4. Curator: As a curator, the teacher assists students in the use and processing of resources while also creating their own digital collections.

5. Gamifier: A special role is played by the gamemaster, who arouses and maintains students' interest in the game during gamification-based learning, introduces them to the rules, and monitors their observance.

6. Influencer: Future roles include the influencer, a social media opinion leader whose activity is followed and imitated by many. If a teacher is able to become an influencer in online media, his / her impact will multiply. The antecedent of the role of influencer in pedagogy is the role model. (Szüts, 2020)

Compared to traditional higher education culture, distance education has highlighted the complexity of the role of educator. Agreeing with other researchers (Serföző et al., 2020), we can say that the task of educators is not primarily the transfer of knowledge in the classical sense, but the mentoring of learning, the support of students and the facilitation of social learning processes during the courses. The need for methodological support for learning is really appreciated, as is the development of a personal learning environment and awareness of learning peculiarities (Rajcsányi-Molnár, 2019). We must also shape and develop our future education system and projects along this line. After all, depending on the specifics of the training programs and courses, different tools, teaching and learning organization methods may be needed (András et al., 2016b., Serföző et al., 2020.).

The development of information and communication technologies has created enormous opportunities to extend the educational process geographically beyond the traditional classroom - online (Ösz et. al., 2013). As we move away from traditional learning and teaching methods, it is critical for online teaching and learning environments that the educator not only strives to learn the technology associated with online learning, but also understands the need for fundamental change and transforms the learning-teaching process as a result, to meet the requirements of online education as well as the needs of students (Keengwe et al., 2010).

Acknowledgments: We thank Victoria Congdon for the English language editing. Her work was supported by the Central Connecticut State University, America.

\section{References}

András I., Rajcsányi-Molnár, M., Bacsa-Bán, A., Balázs, L., Németh, I., Szabó, Cs., \& Szalay, Gy. (2016a). Módszertani megújulás a felsőoktatásban: Az új oktatói szerepnek megfelelő oktatásmódszertani megközelítés. [Methodological renewal in higher education: a methodological approach to teaching for the new teaching role.] Dunakavics, 4(6), 2562.

András, I., Rajcsányi-Molnár, M., Bacsa-Bán, A., Balázs, L., Németh, I., Szabó, Cs., Szalay Gy., \& Ardelean T. (2016b). Tanuláselméletek és az új generációk sajátosságainak vizsgálata a tanulási eredmények alapján. [Learning theories and the characteristics of new generations based on learning outcomes.]. In E. Maior., P. Tóth \& A. Varga (Eds.), Empirikus kutatások az oktatásban határon innen és túl. [Empirical research in education across borders and beyond.] (pp. 355-375). Óbudai Egyetem Trefort Ágoston Mérnökpedagógiai Központ [Óbuda University Trefort Ágoston Centre for Engineering Education].

Benedek, A. (2020). Visual Learning as an Opportunity and Compulsion for Innovation in the Period of Pandemic. In P. Aczél, A. Benedek \& K. Nyíri (Eds.), How Images Behave. (pp. 215-219). Hungarian Academy of Sciences, Budapest University of Technology and Economics. 
Bereczki, E., Horváth, O., Kálmán, L., Káplár-Kodácsy, O., Misley, K., Rausch, H., \& Rónay, A. Z. (2020). Faculty Distance Education Handbook. ELTE Faculty of Education and Psychology.

Dabbagh. N., \& NannaRitland, B. (2005). Online learning: Concepts, strategies and application. Upper Saddle River.

Deés, Sz. (2020). Hallgatói vélemények a COVID-19 világjárvány hatásaként bevezetett online oktatásról. [Students' views on online education introduced in the wake of the COVID-19 pandemic.] Retrieved December 7, 2020, from https://www.edutus.hu/wp-content/uploads/2020/09/26_PDFsam_Acta-Periodica-XX_DOIval-1.pdf

Demeter, R., Kővári, A., Katona, J., Heldal, I., Costescu, C., Rosan, A., \& Thill, S. (2019). A quantitative study of using Cisco Packet Tracer simulation software to improve IT students' creativity and outcomes. In 2019 10th IEEE International Conference on Cognitive InfoCommunications, 353-358.

Demeter, R., Kövári, A., Katona, J., Heldal, I., Costescu, C., Rosan, A., \& Teodor, S. (2020). Cognitive robotics software development aspects based on experiments of future software engineers. In 2020 11th IEEE International Conference on Cognitive Infocommunications, 459-464.

Gonda Gy. (2020). COVID és felsőoktatás. [COVID and higher education.] Retrieved December 7, 2020, from https://azuzlet.hu/covid-es-felsooktatas-forradalom-a-virtualis-tantermekben/

Hargitai, D. M, , Tobak, J., Sasné Grósz, A. \& Veres, Z. (2020). Characteristics of a "COVID-PROOF” HIGHER EDUCATION: How far are we from students' needs?[Abstract from conference].

Howell, S. L., Saba, F., Lindsay, N. K., \& William, P. B. (2004). Seven strategies for enabling faculty success in distance education. Internet \& Higher Education, 7(1), 33-49.

Imets, M. (2020). Tutori munka a távoktatásos gimnáziumi felnőttképzésben. [Tutoring in distance learning in adult education in secondary schools.] Új Pedagógiai Szemle, 57, 12.

Keengwe, J., \& Kidd, T. T. (2010). Towards best practices in online learning and teaching in higher education. Merlot Journal of Online Learning and Teaching, 6(2), 533-541.

Liu, X., Bonk, C. J., Magjuka, R. J., Lee, S. H., \& Su, B. (2005). Exploring four dimensions of online instructor roles: A program level case study. Journal of Asynchronous Learning Networks, 9(4), 29-48.

McKinsey (2020). How the world's best-performing school systems come out on top. Retrieved December 7, 2020, from http://www.mckinseyonsociety.com/downloads/reports/Education/Worlds_School_Systems_Final.pdf 2007

Molnár, Gy. (2021). Methodological and curriculum development-related innovation options and challenges in education in the aftermath of the pandemic. Copus et Educatio: Munka és Nevelés, 8(3), 286.

Molnár Gy., Námesztovszki, Zs., Glušac, D., \& Karuović Dijana; Major L. (2020). Solutions, experiences in online education in Hungary and Serbia related to the situation caused by Covid-19. In IEEE - IEEE (Eds.), 11th IEEE International Conference on Cognitive Infocommunications (CogInfoCom 2020), IEEE, 603-607.

Ösz R., András I., \& Rajcsányi-Molnár M. (2013). Educational Management Questions of New Generation Smart Phones: Mobile Generation in a Changing Learning Environment - Pedagogic Challenges and Paradigms. In I. András, M. Rajcsányi-Molnár (Eds.), Metamorphosis: Glocal Dilemmas in Three Acts (pp. 194-211). Új Mandátum Kiadó.

Rajcsányi-Molnár M. (2019). MaTech: Digitális eszközhasználaton alapuló kreatív matematika verseny szervezése középiskolás tanulóknak. [Organising a creative mathematics competition for secondary school students based on the use of digital tools.] In T. K. Fodorné (Eds.), Felsőoktatási innovációk a tanulás korában: a digitalizáció, képességfejlesztés és a hálózatosodás kihivásai. [Higher education innovation in the learning era: the challenges of digitalisation, skills development and networking.] (pp. 19-32). MELLearN Egyesület.

Rajcsányi-Molnár, M. \& Bacsa-Bán, A. (2021). Úton a digitalizáció felé: egy felsőoktatási intézmény digitális oktatásának hallgatói tapasztalatai. [Towards digitalisation: student experiences of digital education in a higher education institution.] Journal of Applied Technical and Educational Sciences, [Alkalmazott Müszaki és Pedagógiai Tudományos Folyóirat], 11(1), 88-110.

Riffee, W.H. (2003). Putting a faculty face on distance education programs. Syllabus: Technology for Higher Education. Retrieved February 15, 2009 from https://campustechnology.com/articles/2003/01/putting-a-faculty-face-ondistance-education-programs.aspx

Serfőző, M., Golyán, Sz., F. Lassú, Zs., Svraka, B., \& Aggné Pirka, V. (2020). Digitalizáció és online tanulás a pedagógusképzésben - hallgatói visszajelzések a távolléti oktatásról (kutatás közben). [Digitalisation and online learning in teacher education - student feedback on distance learning (research in progress)] Civil Szemle, Különszám, 17, 103-114.

Smith, T. (2005). Fifty-One Competencies for Online Instruction. The Journal of Educators Online, 2(2). https://doi.org/10.9743/JEO.2005.2.2

Sipos, N., Jarjabka Á., Kuráth, G., \& Venczel-Szakó, T. (2020). Felsőoktatás a COVID-19 szorításában: 10 nap alatt 10 év? Gyorsjelentés a digitális átállás hatásairól a munkavégzésben a Pécsi Tudományegyetemen. [Higher education in the 
grip of COVID-19: 10 years in 10 days? A quick report on the impact of the digital switchover on working life at the University of Pécs.] Civil Szemle, Különszám, 17, 71-90.

Szabó, Cs., Andrásm I., \& Rajcsányi-Molnár M. (2017). HASIT: komplex rendszer a felsőoktatási lemorzsolódás csökkentésére. [HASIT: a complex system for reducing early school leaving in higher education.] In J. Kerülö, T. Jenei, T. \& I. Gyarmati (Eds.), XVII. Országos Neveléstudományi Konferencia: Program és absztrakt kötet. [XVII National Conference on Education: programme and abstract.] MTA Pedagógiai Tudományos Bizottság, Nyíregyházi Egyetem.

Szűts Z. (2020). A tanárképzés digitális transzformációjának kevésbé exponált elemei. [Less exposed elements of the digital transformation of teacher education.] Civil Szemle, I. Különszám, 133-144.

UNESCO. Turning the threat of COVID-19 into an opportunity for greater support to documentary heritage. Retrieved December 07, 2020 from unesco.org.

(C) 2021 by the authors. Submitted for possible open access publication under the terms and conditions of the Creative Commons Attribution (CC BY) license (http://creativecommons.org/licenses/by/4.0/). 